\title{
Spinning Them Off: Entrepreneuring Practices in Corporate Spin-Offs
}

\author{
Katja Maria Hydle', Kjersti Vikse Meland ${ }^{2}$
}

\begin{abstract}
This paper focuses on the practices between parent and child firms in corporate spinoffs. We uncover the enacted aspects of knowledge, called knowing, through theories from seven cases of incumbent-backed spin-offs and find that the management of the parent firms are highly involved in the spin-offs. The practices associated with spinning off are solving problems, involving multidisciplinary expertise and entrepreneuring management at the parent firm. We contribute to the spin-off literature by discussing the knowledge required for successfully spinning off child firms and to practice theory by empirically uncovering the practical understanding involved in the origin and perpetuation of an organization.
\end{abstract}

Keywords: corporate spin-offs, knowing, practices, practical understanding.

\section{INTRODUCTION}

In this paper, we uncover the knowledge used in successful spin-off processes. We focus on corporate spin-offs (Bergh, Johnson, \& Dewitt, 2008; Bergh \& Lim, 2008; Bruneel, Van de Velde, \& Clarysse, 2013; Clarysse, Wright, \& Van de Velde, 2011), which are new organizations formed by a split from another organization (Chesbrough, 2002; Clarysse et al., 2011; Wallin, 2012). In particular, we elaborate on the knowledge involved when moving from a parent firm to a new venture.

The knowledge involved in spin-offs has been a subject in research on corporate spin-offs. Clarysse et al. (2011) investigated the technological knowledge characteristics of spin-off performance. They found that narrowfocused technology (having a specific product technology and not a broad technology platform), sufficiently distinct from the technical knowledge base of the parent company and one that is tacit, is beneficial for successful spin-off performance. The forms of knowledge that generate sources of competitive

1 Katja Maria Hydle, Ph.D., Senior Research Scientist, International Research Institute of Stavanger (IRIS), Oslo Science Park, Gaustadalleen 21, 0349 Oslo, Norway, Tel. +47 930058 48, E-mail: katja.hydle@iris.no.

2 Kjersti Vikse Meland, Senior Research Scientist, Polytec, Sørhauggata 128, 5527 Haugesund, Norway, Tel. +47 90981 036. E-mail: kjersti.vikse.meland@polytec.no. 
advantage with a focus on technological based knowledge were found to be important. Technological knowledge is understood here as knowledge related to products, technologies, and processes (Burgers, Van Den Bosch, \& Volberda, 2008). Gained experience and technological knowledge enable the efficient use of knowledge, and evaluation of commercial potential and technological advances (Cohen \& Levinthal, 1990). Another study demonstrated how production, technological, and marketing knowledge were related to the post-spin-off growth of firms spun off from parent firms (Sapienza, Parhankangas, \& Autio, 2004). Research on university spin-offs (Rasmussen, Mosey, \& Wright, 2011) propose to use a competency approach to address competencies provided by several actors while capturing the entrepreneurial processes. They identify three competencies that are needed for a university spin-off including opportunity refinement (having ideas with high knowledge content and technologies that are radical in nature), leveraging (acquiring and combining resources to sustain the new venture creation process), and championing (having a personal commitment or the leadership role needed to sustain the venture start-up process) (Rasmussen et al., 2011, pp. 1328-1336). Although these insights are based on university spin-offs, they are highly relevant for corporate spin-offs.

These insights are highly interesting, and their understanding of knowledge and competencies reflect the resource-based theory of the firm (Barney, 1991; Penrose, 1959; Teece, Pisano, \& Shuen, 1997; Wernerfelt, 1984). According to Wallin (2012), a large part of the spin-off literature concerning entrepreneurship and innovation is heavily influenced by the resource-based view. However, newer theoretical insights underline how this view posits a commodification of knowledge as an asset that can be controlled or transferred (Gherardi, 2000). Leaving the understanding of knowledge and knowledge transfer as something a firm has as an asset, our focus underlines the enacted aspects of knowing (Gherardi, 2000; Gherardi \& Strati, 2012), focusing on what people are doing, erasing the dichotomy between codified/ explicit and personalized/tacit knowledge, as they are found to be inseparably related (Tsoukas, 1996). From understanding competencies and knowledge to a focus on knowing, Orlikowski emphasizes knowing and sets forth that "knowing-how" and practice are mutually constitutive (2002). She follows the understanding of knowing in practice being knowledgeability enacted through on-going action. To uncover knowing in practice, we turn to practice theory as our main theoretical construct because knowledge and knowing are understood to be part of the practical understanding when performing activities that are part of practices (Schatzki, 2012). Using practice theory to grasp the enacted entrepreneuring activities is a powerful frame with which 
to view actionable knowledge (Johannisson, 2011, 2012, 2014; Keating, Geiger, \& McLoughlin, 2014; Steyaert \& Landström, 2011).

Building on the corporate spin-off research exposing that the technical knowledge base that is tacit is beneficial for spin-off performance together with the understanding of knowing, the research questions of this study are as follows: What forms of knowing are important in corporate spin-off creation processes, and what makes spin-offs spin?

This paper, with a focus on the internal relations between parent and child firms, has a twin paper focusing on the external ties to suppliers and customers, which together complement each other in exposing the different practices for successful spin-offs. This paper provides insights into the entrepreneuring practices of spin-off firms and in particular, the types of knowing involved. We find different types of knowing, such as solutionbased knowing, multi-disciplinary knowing, and business set-up knowing, contributing to entrepreneurial literature regarding types of knowing that are important for successful spinning. The contribution to practice theory is empirically to uncover the practical understanding and knowing in relation to the happenings of an organization. We thus contribute to the spin-off literature and practice theory regarding the practices and inherent knowing when establishing an independent organization.

\section{LITERATURE REVIEW}

Existing research on corporate spin-offs has emphasized how firm policies give incentives for employee innovation and entrepreneurship (Hellmann, 2007). When the parent firm assists or takes part in spinning off a company, it is called an incumbent-backed spin-off (Bruneel et al., 2013). These types of spin-offs are triggered by an opportunity, but the parent firm is behind the spin-off, not the employees. These opportunity spin-offs are in opposition to necessity spin-offs or strategic restructuring spin-offs, which are due to adverse developments (Bruneel et al., 2013). Incumbent-backed spin-offs are established by the parent firm to explore new products and services in the market. Because these products or services are not part of the parent firm's core strategy, it is more prudent to develop and commercialize these in an independent legal entity (Parhankangas \& Arenius, 2003). According to Agarwal \& Bayus (2002), the development time of their product or service may take over 10 to 15 years before launch. Parent firms are involved in hiring or establishing the managerial positions at the spin-off firm, and these managers seem to operate under the umbrella of the incumbent (Bruneel et al., 2013). The formal ties between the parent firm and the spin-off are through equity or license agreements (Parhankangas \& Arenius, 2003), 
with ongoing parent participation in the spin-off. According to Grant (1996), understanding the relations between the parent and the spin-off firms may enhance our insights of what knowledge is needed internally in the spin-off and to evaluate external knowledge needed for the spin-off. These insights are highly valuable for exploring the knowledge involved in spin-offs, and we lean on practice theory.

Practice theory understands practices as a set of organized activities (Schatzki, 2012). These activities are formed by basic doings and sayings. Activities performed for a certain reason form a practice, involving interdependent persons who modify their responses as they interact (Schatzki, Knorr Cetina, \& von Savigny, 2001). A practice embraces i) the practical understanding of the actions composing the practices, ii) rules, iii) teleological structures and, iv) the general understanding of the nature of work (Schatzki, 2005). The practical understanding is also referred to as the complex of know-hows (Schatzki, 2006), which is important to understand in relation to organized activities. "By 'practical understanding,' I mean knowing which bodily actions to perform (in particular circumstances) in order to accomplish specific actions" (Schatzki, 2013, p. 34). In this paper, we focus on the practical understanding comprising the practices.

Practical understanding and knowing cannot be made totally explicit. Building on Heidegger (2008) and Wittgenstein (1953/2009), Schatzki explains that "knowing how to go on is a mastery of ways of speaking and acting that defies adequate representation in words, symbols, diagrams or pictures. This fact undermines the claim that practical understanding is being able to apply a formula" (1997, p. 299). Actions and activities are understood to be organized by practical understanding and tacit knowledge, the knowing. Because we want to look at practices between parent and child firms, to identify the knowing involved, we will uncover their particular practices. However, we do not focus on the workings of the organization, but more on the origin and the perpetuation of the organization (Schatzki, 2005). According to Schatzki (2005), to comprehend an organization, we have to identify the actions that comprise it. An organization is made of actions that are performed in existing practices and with a mix of old and new practices and material arrangements, and an organization maintains the existence of practices while accommodating changes.

The emergence, persistence, and dissolution of practices are explained as slices of social phenomena (Schatzki, 2013). The emergence of practices in relation to practical understanding is explained to be "the development of common practical understanding" (Schatzki, 2013, p. 37). However, there is a lack of explanations of how practical understanding and complexes of knowhows are involved in relation to the happening of an organization. Apart from 
the abstract and general terms of descriptions regarding the happenings of an academic department with practices of grading, teaching, and research (Schatzki, 2006), there is a lack of theorizing into the practical understanding and knowing in relation to the happening of organizations. We delve into the happening of spin-offs and the carrying out of their constituent practices. Focusing on incumbent-backed spin-offs, we examine the practices between the parent firm and the child firm when spinning off the independent organization.

\section{RESEARCH METHODS}

To uncover the knowing and the particular practices involved with spinoffs, we treat practices, and their inherent activities, as the central lens to understand the spin-off organization. By examining the recurrent practices of the actors involved, we aim to uncover the knowing.

\section{Empirical material}

The study is based on empirical materials derived from 25 interviews in seven cases of spin-offs. We conducted semi-structured interviews regarding the spin-off process from the beginning to the present situation, posing detailed questions as to what they did and which activities they undertook. When inquiring about the spin-offs, we have investigated the spin-offs from idea to establishment regarding internal and external actors involved, use of existing innovation processes, access to financial support, use of established or emergent networks, experience needed, and knowledge and capabilities involved. For every case, the aim was to interview the actors involved during the spinning-off process. However, we found that there were often not that many people actually involved, which made us change the interview scope to include the CEO or the strategic manager behind the spin-off both from the parent firm and the child firm. During our interviews, we also found that there were often particular third persons involved in the spin-off process. This finding made us enlarge the interview scope for those spin-off cases that were relevant to include interviews with a third party who had closely followed the spin-off process, such as investors, board members, customers, or suppliers. The unit of analysis is the practice of spin-offs from the idea to the actual commercialization. We followed semi-structured interview guides and had slightly different versions of the guide dependent on whether the informant represented the parent firm, the child firm, or a third party. However, the content and topics of the interviews remained the same: the entire history from the early idea to spinning-off the company; the phases from the idea for establishing the spin-off, the incubation phase, and the commercialization 
phase; who was involved and their different roles; what activities were undertaken and what decisions were made; the market situation for the mother firm and the spin-off in relation to the process, service, or product that was part of the spin-off; internal strategies and activities at the parent firm in relation to the spin-off; external actors involved and their activities; financial needs and inherent activities undertaken; and finally, the current situation and relation to the spin-off, parent firm, or other third parties. Each interview lasted between one to two hours. The interviews were recorded and transcribed.

The seven cases of incumbent backed spin-offs were found based on our informal inquiries within different industries, in which slowly, over several months, we were told about several cases from word of mouth. The spin-off cases represented the oil and gas, maritime, and information and communication technology (ICT) industries. Our cases are opportunity spin-offs, where spin-offs result from the exploitation of an opportunity by employees, and parent-backed spin-off, initiated by parent firms (Bruneel et al., 2013). To preserve anonymity, we denote the cases from 1 to 7 and by whether the interviews stem from parent firms, child firms, or third parties (Table 1).

Table 1. Overview of interviews in parent and child firms and third party interviews

\begin{tabular}{llll}
\hline Spin-offs & $\begin{array}{l}\text { Parent firm } \\
\text { interviews }\end{array}$ & Child firm interviews & 3rd party interviews \\
\hline 1 & 2 & 1 & 2 \\
2 & 1 & 1 & 1 \\
3 & 2 & 2 & \\
4 & 1 & 1 & 1 \\
5 & 2 & 1 & 1 \\
6 & 1 & 1 & 1 \\
7 & 2 & 1 & \\
7 Spin-offs & 11 interviews & 8 interviews & 6 interviews \\
\hline
\end{tabular}

Table 2 exposes the different cases, where we understand spin-off success as still being in business with positive revenues. During our inquiries, case 2 was still in the process of spinning-off. Meanwhile Case 5 was dissolved, as the spin-off child firm closed down, and the employees returned to the mother company. 
Table 2. Overview of the different cases of parent and spin-off companies

\begin{tabular}{llllll}
\hline Case & $\begin{array}{l}\text { Parent company } \\
\text { established }\end{array}$ & $\begin{array}{l}\text { Spin-off } \\
\text { established }\end{array}$ & $\begin{array}{l}\text { No of employees } \\
\text { in 2014 }\end{array}$ & Revenues & $\begin{array}{l}\text { Spin-off } \\
\text { success }\end{array}$ \\
\hline 1 & 1966 & 2012 & 20 & Positive results & Yes \\
2 & 2010 & 2014 & 2 & Not yet & On-going \\
3 & 1987 & 2004 & 30 & Positive results & Yes \\
4 & 1979 & 2004 & 10 & Positive results & Yes \\
5 & 1973 & 2012 & None & Positive results & $\begin{array}{l}\text { No (Dissolved } \\
\end{array}$ \\
6 & 1999 & 2013 & 20 & Positive results & Yes \\
7 & 1948 & 2006 & 33 & Positive results & Yes \\
\hline
\end{tabular}

\section{ANALYSIS}

The analysis was conducted in several steps. First, the data were examined in relation to the research questions, with specific consideration of what activities were involved in the spin-offs to identify the knowing. During the interviews and the data analysis, we found that the management from the parent companies seemed as dedicated to the spin-off as the spin-off CEOs. We were surprised when identifying how close the parent companies' managements were to the spin-offs. Iterating between in-depth analysis of the empirical findings from each spin-off case and comparisons across the spin-off cases, and connections to the literature (Alvesson \& Kärreman, 2007), we thus returned to extant theorizing and found the characteristics of incumbent-backed spinoffs were in line with our findings; however, our findings highlighted activities that were undertaken, which the existing literature does not expose. Across the cases, the spin-off practices and knowing involved were also surprisingly similar, and we did not find differences related to industries, which is why we do not focus on the related industries. However, the interviews reflected whom we had talked to and whether they represented the parent firm, the spin-off firm, or third parties. The difference was in relation to viewpoint, although the stories told about the spin-offs were coherent. We thus coded our collected material according to the literature on incumbent-backed spinoffs (Bruneel et al., 2013), inspired by the work from Orlikowski regarding practices of knowing (2002). By using practices, activities comprising the practice and the knowing constituted in the practice to explore the data, we found variations within each theme, which are reported in the findings section and further analyzed in the discussion and conclusion section. 


\section{Analysis/study}

We found three central practices of spin-offs (Table 3). First, spin-off ideas, whether related to products, technologies, or services, were based on practical solutions and problem solving. Second, the spin-off required multidisciplinary expertise for the business idea to be carried out. Third, the parent firm showed entrepreneuring management through supporting innovation, being pro-active, and taking risks. The three practices of solving problems involving multidisciplinary expertise and entrepreneuring management are discussed in relation to the activities comprising the practices and the knowing constituted in the practice and illustrated with the quotes in the following section.

Table 3. Repertoire of practices, activities, and knowing for spin-offs

\begin{tabular}{|c|c|c|}
\hline Practice & Activities comprising the practice & $\begin{array}{l}\text { Knowing constituted } \\
\text { in the practice }\end{array}$ \\
\hline Solving problems & $\begin{array}{l}\text { Engaging in handling challenges } \\
\text { Identifying unconventional solutions }\end{array}$ & $\begin{array}{l}\text { Knowing based on } \\
\text { questioning common } \\
\text { assumptions }\end{array}$ \\
\hline $\begin{array}{l}\text { Involving } \\
\text { multidisciplinary } \\
\text { expertise }\end{array}$ & $\begin{array}{l}\text { Collaborating with professionals with different } \\
\text { backgrounds and skills } \\
\text { Developing solutions together }\end{array}$ & $\begin{array}{l}\text { Knowing different } \\
\text { facets of the same } \\
\text { industry }\end{array}$ \\
\hline $\begin{array}{l}\text { Entrepreneuring } \\
\text { management }\end{array}$ & $\begin{array}{l}\text { Accepting internal projects } \\
\text { Having short decision-making lines } \\
\text { Adhering to a management philosophy of } \\
\text { nurturing employee-driven innovation } \\
\text { Establishing a company } \\
\text { Hiring the CEO for the spin-off } \\
\text { Establishing security for employees leaving the } \\
\text { parent firm } \\
\text { Being part of the board } \\
\text { Sharing experiences } \\
\text { Securing funding }\end{array}$ & $\begin{array}{l}\text { Knowing how to } \\
\text { set up and run } \\
\text { businesses }\end{array}$ \\
\hline
\end{tabular}

\section{Solving problems}

The original idea behind the spin-off stemmed from different sources within the parent company. In case 2, we find the original idea came from the CEO of the parent firm. "I do not know what the CEO (at parent firm) has said, but the idea of the spin-off is probably his. It had to do with an idea based on a system that was developed in an earlier company established by the CEO. He came up with the idea and wanted me to develop it in collaboration with him. But clearly the technology and the way the architecture and everything is, how it should be built up and stuff, I helped him with that. But, we should probably say that the idea for the product stemmed from the CEO" (Case 2, CEO Parent firm). 
The spin-off managers emphasized that the idea behind the spin-off appeared during solving practical questions or during projects within the parent firm. One of the informants in case 4 explained: "This had its origin from engineering. These are people with engineering backgrounds. It's a combination of ideas either from me, or Ole, or others... The first obstacle is... because everyone thinks like that in conventional terms. With the existing technology, if you take topside technology and put it at the seabed, then you will get no advantages, only disadvantages. So you have to change the entire mind-set, and see what kind of advantages we get at seabed instead of topside, and then exploit the advantages and not the disadvantages. Then, you can do things all differently, and suddenly there are things that are easier and more efficient at seabed due to other reasons" (Case 4, CEO Child firm).

The ideas behind the spin-off are based on solving problems or seeing new solutions to existing challenges. The knowing involved was based on questioning common assumptions. The origin of the ideas stemmed both from managers in the parent firms and from managers in the newly established spin-off firms.

\section{Involving multidisciplinary expertise}

We also found that competencies from different fields, with experience from different segments of the industry, were important to deliver the services and products of the spin-offs. "The core thing that makes us successful is that we have good knowledge, broad knowledge. Old experience and people that have worked a long time with different things in the offshore segment, tried many things and have very good knowledge of materials, for example. We try to get them to work closely together, and talk together well" (Case 3, CEO Parent firm).

The findings suggest that multidisciplinary expertise is highly important. "We don't chase solutions based on volumes on behalf of safety. It is competence and experience. That is what we can do...The idea is that we are going to do it, and we will do it our own way... We deliver a spectrum of services. To deliver multidisciplinary is what allows us to manage the extraordinary ..." (Case 1, CEO Parent firm).

In some cases, the multidisciplinary expertise is explained through the competence and experience that the employees in the spin-off have acquired: "I think that we have people with a larger perspective, which we see even in relation to oil companies. Here we can be three men, and then we have the competence. I have worked in operations, another has worked with reservoir simulations, another with all kinds of subsea fields, and suddenly we have this competence that even if we meet with twenty men, they do not 
match us since they are either facility people or something else ... " (Case 4, CEO Child firm).

Involving multidisciplinary expertise entails collaborating with colleagues with different backgrounds and skills to develop solutions together. The CEOs talk about "managing the extraordinary," "they do not match us," "work closely together," and "talk well together." Their multidisciplinary knowing involved different facets within the same industry.

\section{Entrepreneuring management}

In the seven cases of spin-offs, the parent firms reported that they had an explicit focus on innovation and entrepreneurship. They welcomed internal innovation projects or found new solutions to existing challenges as a reason to spin off. Short decision-making lines were emphasized as important for the internal innovation projects and for new solutions to see light: "There is a very short distance and low threshold to speak to the CEO, so everyone can talk to him. When good ideas are brought up, it is very easy to get a 'go for it' from the CEO" (Case 1, Brand Manager Parent firm).

"And then you have the decision-making lines. For us to be able to do anything together, we have to have decisions. And short decision-making lines are an asset. I really believe that this is important, since when there is an established spin-off, we get a mandate, a board and a budget and then you can drive. You cannot do that if you are a unit in a large corporation" (Case 7, CEO Child firm).

The management in the parent companies adhered to a management philosophy of nurturing employee-driven innovation, as shown in the explanation from the CEO in case 4: "But I believe that it is important that there are ideas realized since we are within the technical fields. Then, we who are managers, we have the damn duty to assure that these ideas are developed, even at a personal level. I mean that" (Case 4, CEO Parent firm).

The parent management was involved in establishing the spinoff company: "We have done this, spinning off companies, many times before. Both before and after" (Case 7, CEO parent company). The parent management was also involved in hiring the CEO for the spin-off company: "So they established a project ... And they began to create something physical, and measured and tested. We drove the entire first phase without moving the company out. But when we began to see that now we had to move this out, initially we employed the CEO and another person in the new company. And they moved physically out" (Case 4, CEO Parent firm).

"We started out with.... we [Parent firm 2] had collaboration with parent firm 1 so we knew each other. And together we saw the need to have a stable 
collaboration partner regarding these multidisciplinary services. We had collaborated with another firm over many years, but they were owned by a large corporation and on several occasions we were not prioritized. This was the reason why we [Parent firm 1 and 2] sat down and carved out a strategy so that we could get more control of those services we were dependent on. And that was how we [CEO parent firm 1 and CEO parent firm 2] decided to start the spin-off, which we did a few years ago. We started it rather heavy, with engineers, managers, CEO and everything, without any projects or jobs to do..." (Case 7, CEO Parent firm 2).

The parent firm management emphasized the importance of establishing security for employees leaving the parent firm to the spin-off company. Several of the CEOs from the parent firms were part of the board of the spinoff companies and hence secured the on-going operations of the spin-off through sharing experiences and ensuring smooth operations.

"We have the advantage that we own 49\%, and half of the profit comes back to us. Then, we are on the board, so we know what is going on. We can make requirements based on accounting principles and all that, so we know we are not taking any risk regarding taxes, etc....so that we ensure we are not engaged in anything that is unreliable" (Case 7, CEO Parent firm).

Thus, the spin-off companies benefit from different administrative procedures, routines, or experiences than the parent company. Through the board representation, the parent company further secured funding for the spin-off operations. "We gambled and said, 'Now let's try it, to test it out in the market, whether there is someone who is willing to pay for this. Does it have a value?' Then we went out and did a placement and invited new shareholders. At that time, the company was valued at about 100 million. And the amount we received was 35 million or something, and then the ball started rolling" (Case 4, CEO Parent firm).

Several spin-off cases talked about the challenge of financing the development of new products and services. Of course, the dimension of this challenge varies enormously depending on the type of product/service. The most extreme case of development among our sample was said to last $10-12$ years and cost approximately USD $10-13$ million. The majority of companies interviewed claimed that it is difficult to justify spending millions on development. "The board simply won't allow it" (Case 4, CEO Child firm).

"When we had the idea, we were working at the parent company, a large Norwegian-owned company dealing with topside engineering [design and modification of fixed offshore installations]. The profit margins in such companies do not allow large scale development work with no secure income stream 'just around the corner'"' (Case 4, CEO Child firm). 
This challenge was solved in a variety of ways. Some companies got by through a combination of venture capital and public R\&D support. A commonly used tax program that refunds $20 \%$ of the development costs assisted several of the spin-offs. Others used their own funds.

A lack of support from parent firm management, which seemed to be strategically based, was a make or break for the spin-offs. Two of the cases had problems with gaining thorough support from the parent firms: "A lot of the development work for the product has been done in our spare time as our board does not like us working on work with no income stream. Naturally, this delays the development work" (Case 2, CEO Child firm). All our cases had solid support from the parent firm management except in Case 5, which was dissolved in spite of sound management and positive results. "A bit of resistance internally at the parent firm, to go for large multi-projects, was also a reason why it did not work" (Case 5, CEO Child firm). The parent firm explained: "We did an overview of the investments that had to be done, and who should take them. And when it came to the board table, the Board said that there is too much uncertainty, too much risk, and too many large investments, so we said no. So that was why and as a sort of consequence, we froze this company" (Case 5, COO Parent firm).

Apart from Case 5, all the spin-offs are still in business, and the management of the parent firms exposed entrepreneurial attitudes, using their experience to enable the spin-off companies, exposing knowing how to set up and run a business.

\section{Discussion}

This study set out to answer the following questions: What forms of knowing are important in successful spin-off creation processes, and what makes spin-offs spin? With a focus on practices, the activities comprising the practices and the knowing constituted within the practices, we found that entrepreneuring management and their activities and knowing from the idea to the very realization of the spin-off and the further operationalization of the spin-off were critical. Our findings expose that for incumbentbacked spin-offs, solving problems involving multidisciplinary expertise and entrepreneuring management were the practices involved in spinning-off parent and child firms. These three practices resemble, but are not identical to, the competencies found for university spin-offs, which were described as opportunity refinement, leveraging, and championing (Rasmussen et al., 2011). The main differences in our findings are due to the nature of university spin-offs, involving academics becoming accustomed to business, and corporate spin-offs, involving businesses establishing new businesses. 
Our findings both confirm and extend the existing research. The parent firms' management accepting internal projects shows how firm policies give employees incentives for employee-driven innovation in line with Hellmann (2007). However, our findings expose how these incentives are operationalized through internal acceptance of innovative projects, with short decision-making lines, and with a management adhering to a management philosophy of nurturing employee-driven innovation, which extends and further nuances the existing research. Extant research emphasizes that incumbent-backed spin-offs are triggered by an opportunity and that the management of the parent companies are involved in the set-up of the spinoff (Bruneel et al., 2013). Our findings confirm this by exposing how close the parent firm management is to the spin-off process. Sapienza et al. (2004) found that production and technological knowledge relatedness between parent and child firms were related to growth, while our findings expose that support from the parent firm is imperative for the organizational happening of the child firm. Grant (1996) emphasized that understanding the relations between the parent and the spin-off firms would enhance our ability to understand what knowledge is needed internally and evaluate external knowledge. Our findings show that the relations between parent and child firms both established security for employees in the spin-off firm, and by being part of the board, they shared experiences of how to run a business, secure funding, and develop the spin-off company using the knowing from the parent firms. Our findings and answer to the first research question, nuance the existing research by emphasizing that the knowing involved for successful spin-offs are: knowing how to question established assumptions, knowing the facets of the industry, and knowing how to run a business. This complex of know-hows, or knowing, exposes how practice theory and the practical understanding involved in the happening of an organization is a helpful theoretical lens for spin-off theorizing and entrepreneurial processes.

Turning to practice theory, we found the practices for establishing an independent organization. The answer to our second research question regarding the happening of spin-offs and the constituent practices was solving problems, involving multidisciplinary expertise and entrepreneuring management. By focusing on the internal practices needed during the occurrence of spin-offs, we expose what practice theory refers to as the practical understanding (Schatzki, 2006). Our contribution is hence the identification of what is necessary for an organization to happen. Our findings are shown in Figure 1. The activities and practices are not necessarily sequential or linear because they can be performed in parallel, but they are exposed here for illustrative purposes: 


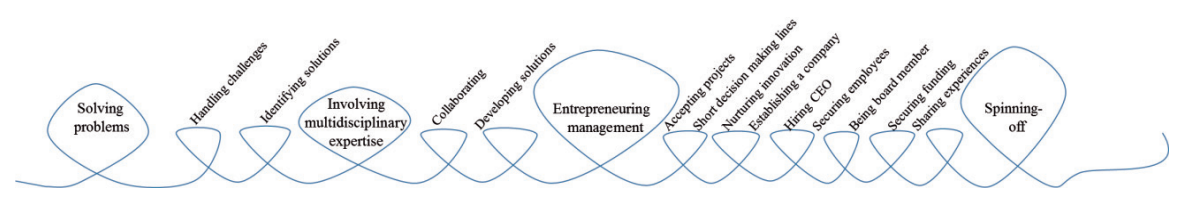

Figure 1: Practices for spinning off

\section{CONCLUSION}

This paper focuses on spin-offs and the necessary knowledge and experience involved. By highlighting the enacted aspects of knowing, we show the activities comprising the practices and the different practices involved between the parent and spin-off firms during the process of spinning off. A limitation of this study is that we have not been able to follow the spinning-off process over time, but we have inquired about the process in retrospect. To address this shortcoming, we also interviewed third party actors who could explain more of the practices from another angle. Highlighting the spin-offs from three different angles is clearly a strength with the empirical material, which enabled us to identify the practices and the knowing involved. We find that there is a close relation between the parent firms and spin-off firms in relation to knowing and the actors involved in the spin-offs. Entrepreneuring management from the parent firms and committed employees in child firms are highly important for successful spin-offs. By finding different types of knowing, such as solution-based knowing, multi-disciplinary knowing, and business set-up knowing, we contribute to the entrepreneurial literature regarding types of knowing that are important for successful spinning-off. Although we have solely focused on spin-offs, the practices identified are relevant to other types of organizations where there are actors from different organizations involved in the establishment of a new organization. Future studies could delve into the practices of parent and child firms during and after spinning-off to uncover the practices that are used.

\section{References}

Agarwal, R., \& Bayus, B. L, (2002). The market evolution and sales take-off of product innovations: Management Science, 48(8), 1024-1041.

Alvesson, M., \& Kärreman, D. (2007). Constructing mystery: Empirical matters in theory development. The Academy of Management Review, 32(4), $1265-1281$.

Barney, J. B. (1991). Firm resources and sustained competitive advantage. Journal of Management, 17, 99-120. 
Bergh, D. D., Johnson, R. A., \& Dewitt, R.-L. (2008). Restructuring through spin-off or sell-off: Transforming information asymmetries into financial gain. Strategic Management Journal, 29(2), 133-148.

Bergh, D. D., \& Lim, E. N.-K. (2008). Learning how to restructure: Absorptive capacity and improvisational views of restructuring actions and performance. Strategic Management Journal, 29(6), 593-616.

Bruneel, J., Van de Velde, E., \& Clarysse, B. (2013). Impact of the type of corporate spin-off on growth. Entrepreneurship: Theory \& Practice, 37(4), 943-959.

Burgers, J. H., Van Den Bosch, F. A. J., \& Volberda, H. W. (2008). Why new business development projects fail: Coping with the differences of technological and market knowledge. Long Range Planning, 41, 55-73.

Chesbrough, H. W. (2002). Graceful exits and missed opportunities: Xerox's management of its technology spin-off organizations. Business History Review, 76(4), 803-837.

Clarysse, B., Wright, M., \& Van de Velde, E. (2011). Entrepreneurial origin, technological knowledge, and the growth of spin-off companies. Journal of Management Studies, 48(6), 1420-1442.

Cohen, W. M., \& Levinthal, D. A. (1990). Absorptive capacity: A new perspective on learning and innovation. Administrative Science Quarterly, 35, 128152.

Gherardi, S. (2000). Practice-based theorizing on learning and knowing in organizations. Organization, 7(2), 211.

Gherardi, S., \& Strati, A. (2012). Learning and knowing in practice-based studies. Cheltenham, Elgar Publishing, Inc.

Grant, R. (1996). Toward a knowledge-based theory of the firm. Strategic Management Journal, 17, 109-122.

Heidegger, M. (2008). Being and time (J. Macquarrie \& E. Robinson, Trans. 7 th ed.). New York: Harper Perennial Modern Thought.

Hellmann, T. (2007). When do employees become entrepreneurs? Management Science, 53(6), 919-933.

Johannisson, B. (2011). Towards a practice theory of entrepreneuring. Small Business Economics, 36(2), 135-150.

Johannisson, B. (2012). Tracking the everyday practices of societal entrepreneuring. In K. Berglund, B. Johannison, \& B. Schwartz (Eds.), Societal entrepreneurship positioning, penetrating, promoting (pp. 6088). Cheltenham, Edward Elgar Publishing, Inc.

Johannisson, B. (2014). The practice approach and interactive research in entrepreneurship and small-scale venturing. In A. Carsrud \& M. Brännback (Eds.), Handbook of research methods and applications in entrepreneurship and small business (pp. 228-258). Cheltenham, Edward Elgar Publishing, Inc.

Keating, A., Geiger, S., \& McLoughlin, D. (2014). Riding the practice waves: Social resourcing practices during new venture development. Entrepreneurship: Theory \& Practice, 38(5), 1207-1235. 
Orlikowski, W. J. (2002). Knowing in practice: Enacting a collective capability in distributed organizing. Organization Science, 13(3), 249-273.

Parhankangas, A., \& Arenius, P. (2003). From a corporate venture to an independent company: A base for a taxonomy for corporate spin-off firms. Research Policy, 32, 463-481.

Penrose, E. (1959). The theory of the growth of the firm. Oxford: Oxford University Press.

Rasmussen, E., Mosey, S., \& Wright, M. (2011). The evolution of entrepreneurial competencies: A longitudinal study of university spin-off venture emergence. Journal of Management Studies, 48(6), 1314-1345.

Sapienza, H. J., Parhankangas, A., \& Autio, E. (2004). Knowledge relatedness and post-spin-off growth. Journal of Business Venturing, 19(6), 809-829.

Schatzki, T. (2013). The edge of change: On the emergence, persistence, and dissolution of practices. In E. Shove \& N. Spurling (Eds.), Sustainable Practice: Social Theory and Climate Change (pp. 31-46). New York: Routledge.

Schatzki, T. R. (1997). Practices and actions: A Wittgensteinian critique of Bourdieu and Giddens. Philosophy of the Social Sciences, 27(3), 283-308.

Schatzki, T. R. (2005). Peripheral vision: The sites of organizations. Organization Studies, 26(3), 465-484.

Schatzki, T. R. (2006). On organizations as they happen. Organization Studies, 27(12), 1863-1873.

Schatzki, T. R. (2012). A primer on practices: Theory and research. In J. Higgs, R. Barnett, S. Billett, M. Hutchings \& F. Trede (Eds.), Practice-based education: Perspectives and strategies (pp. 13-26). Rotterdam: Sense Publishers.

Schatzki, T. R., Knorr Cetina, K. D., \& von Savigny, E. (Eds.). (2001). The practice turn in contemporary theory. London: Routledge.

Steyaert, C., \& Landström, H. (2011). Enacting entrepreneurship research in a pioneering, provocative and participative way: On the work of Bengt Johannisson. Small Business Economics, 36(2), 123-134.

Teece, D. J., Pisano, G., \& Shuen, A. (1997). Dynamic capabilities and strategic management. Strategic Management Journal, 18(7), 509-533.

Tsoukas, H. (1996). The firm as a distributed knowledge system: A constructionist approach. Strategic Management Journal, 17, 11-25.

Wallin, M. W. (2012). The bibliometric structure of spin-off literature. Innovation: Management, Policy \& Practice, 14(2), 162-177.

Wernerfelt, B. (1984). A resource-based view of the firm. Strategic Management Journal, 5, 171-180.

Wittgenstein, L. (1953/2009). Philosophical investigations (G. E. M. Anscombe, P. M. S. Hacker \& J. Schulte, Trans. Revised 4th ed.). West Sussex, UK: Wiley-Blackwell. 


\begin{abstract}
Polish)
Niniejszy artykuł skupia się na praktykach między spółkami dominujqcymi (matka) a zależnymi (córka) w korporacyjnych firmach typu spin-off. Ujawniamy w nim stanowione aspekty wiedzy, zwane knowing, poprzez teorie oparte na siedmiu przypadków firm typu spin-off wspieranych przez duże podmioty działajqce wcześniej w branży, oraz wykazujemy silne zaangażowanie kadry zarzqdzajqcej spółkq matkq w działalność firmy spin-off. Praktyki zwiqzzane z procesem wyodrębniania spółek typu spin-off to rozwiqzywanie problemów, wykorzystanie wiedzy eksperckiej z wielu dyscyplin, a także przedsiębiorcze zarzq̨dzanie w firmie macierzystej. Literaturę na temat firm spin-off dopełniamy omawiajq̨c wiedzę niezbędna do skutecznego tworzenia spółek zależnych, natomiast teorię uzupetniamy poprzez empiryczne ukazanie praktycznych aspektów powstania organizacji, jak również jej utrwalania.
\end{abstract}

Słowa kluczowe: korporacyjne firmy spin-off, wiedza, praktyki.

\title{
Biographical notes
}

Katja Maria Hydle is a senior research scientist at the International Research Institute of Stavanger. She received her PhD in Strategic Management from BI Norwegian Business School. Her research concentrates on innovation, professional service work, organisational practices and multinational companies.

Kjersti Vikse Meland is a senior research scientist at Uni Research Polytec. Meland has an M.Sc. in marketing from Buskerud University College in Norway. Her research concentrates on innovation, entrepreneurship, clusters and regional development. Meland has long experience in research on innovation and regional development. 
